\title{
Did Jean-Martin Charcot Contribute to Stroke?
}

\author{
Julien Bogousslavsky ${ }^{a}$ Maurizio Paciaroni ${ }^{b}$ \\ ${ }^{a}$ Genolier Swiss Medical Network, Clinique Valmont, Glion/Montreux, Switzerland; b Stroke Unit and \\ University Division of Cardiovascular Medicine, Santa Maria della Misericordia Hospital, Perugia, Italy
}

\section{Key Words}

Charcot, Jean-Martin $\cdot$ History of neurology $\cdot$ Stroke $\cdot$ Brain infarction $\cdot$ Cerebral hemorrhage $\cdot$ Cerebral aneurysm $\cdot$ La Salpêtrière

\begin{abstract}
Stroke was never identified as a significant, autonomous field of activity of the emerging school of neurology at La Salpêtrière, which developed after the appointment of JeanMartin Charcot (1825-1893) during the last days of 1861. However, stroke was already present in Charcot's first paper (1851), which dealt with a case of multiple organ cardiac embolism, including middle cerebral artery infarction, at a time when the studies of Rudolf Virchow on thromboembolism were unknown in France. A few years later, Charcot made a still up-to-date description of vascular intermittent claudication, which had only been reported in the horse. In the 1860s, Charcot and his pupils presented several major works dealing with cerebrovascular disease, including famous studies on miliary aneurysms in cerebral hemorrhage. This work was done with Charles Bouchard, at the time Charcot's 'interne', but who would become one of his 'political' opponents 2 decades later, when in 1892, as president of the 'agrégation' jury, he rejected the professorship application of 4 protégés of Charcot, including Joseph Babinski and Georges Gilles de la Tourette. Further work on cerebrovascular disease by
\end{abstract}

Charcot included histological studies of brain 'softening', paraneoplastic cerebral arterial occlusion and consequences of stroke (e.g. arthropathies, vegetative changes, contractures and abnormal movements). Brain localization, one of Charcot's major neurological topics, was also largely based on stroke case studies. Charcot's work on stroke remains poorly recognized, but it demonstrates his unique skills in stimulating scientific work in younger colleagues, many of whom subsequently became major figures of neurology and psychiatry.

Copyright $\odot 2010$ S. Karger AG, Basel

Jean-Martin Charcot (1825-1893; fig. 1) is rightly considered as the father of neurology in France, and his extraordinary clinical and scientific activity attracted a high number of local and international pupils to La Salpêtrière hospital, where he was appointed in November 1861, starting work on 1 January 1862. Charcot's major interest and expertise encompassed hysteria and hypnotism, motor neuron disease (amyotrophic lateral sclerosis was named 'Charcot's disease'), locomotor ataxia (tabes dorsalis), multiple sclerosis, Parkinson's disease, cerebral localization and art in neurology $[1,2]$. In the last edition of his summarized published work [3], studies on the nervous system cover nearly 100 pages, but it is remarkable that 63 pages are on nonneurological studies.

\section{KARGER}

Fax +4161306 1234 E-Mail karger@karger.ch www.karger.com
(C) 2010 S. Karger AG, Basel 0014-3022/10/0641-0027\$26.00/0

Accessible online at: www.karger.com/ene
Julien Bogousslavsky, MD

Genolier Swiss Medical Network

Clinique Valmont

$\mathrm{CH}-1823$ Glion/Montreux (Switzerland)

Tel. +41 21962 3700, Fax +41 21962 3838, E-Mail jbogousslavsky@valmontgenolier.ch 


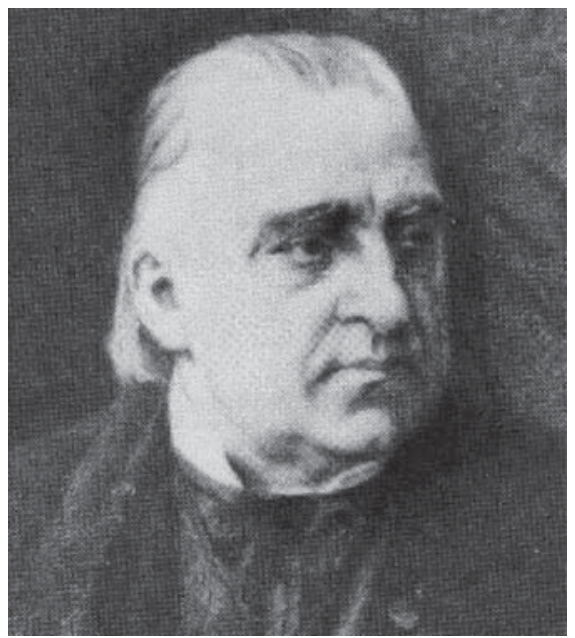

Fig. 1. Jean-Martin Charcot (1825-1893). Courtesy O. Walusinski, MD.

Indeed, Charcot's first works were done in what is now called internal medicine, with his doctorate thesis on gout in 1853 [4], and reports to the Société de Biologie on acute rheumatism, fibrinoid tumors or 'pied-bot varus', starting in 1851 [3, No. 26, 28, 181, pp. 27 and 170]. In the same year, however, nervous system disorders were already present in Charcot's work, as he presented a case of fungal infection of the meninges, along with Claude Bernard [3, No. 160, p. 161], and a case of tumor compression of the medulla oblongata and emerging nerves. One year later, he reported a case of brain atrophy with atrophy and deformation of one half of the body with M. Turner [3, No. 70, p. 74], which Jules Cotard would use in 1868 in his famous thesis on partial brain atrophy [5].

Apart from the well-known report on small aneurysms associated with cerebral hemorrhage (CharcotBouchard aneurysms), cerebrovascular disease and stroke are remarkably absent from reviews on Charcot's work, and we have counted only 9 papers dealing with stroke among 462 publications. However, it is striking that in 1851, what seems to be the first of Charcot's reports to the Société de Biologie was devoted to multiple organ infarcts in a case of rheumatic fever with endocarditis, which included a cerebral 'softening' ('ramollissement') associated with hemiplegia [3, No. 26, p. 27], at a time when the work of Rudolf Virchow on embolism [6] was still unknown in France. Thereafter, mainly in the 1860s and 1870s, Charcot's contribution to cerebrovascular disease and stroke was far from being nonsignificant, but it has been somewhat erased by more 'fashionable' topics, such as hysteria and hypnotism.

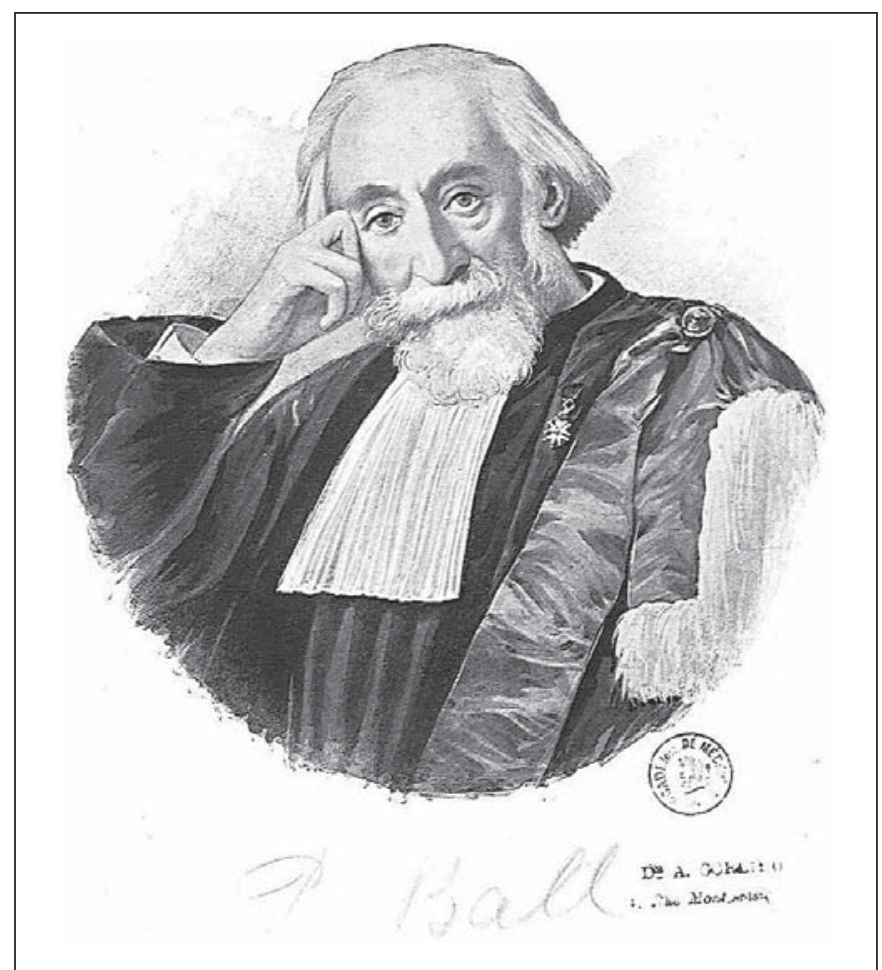

Fig. 2. Benjamin Ball (1833-1893). Charcot became the first holder of the first chair of neurology ('chaire de clinique des maladies du système nerveux') in 1882 and Ball the first holder of the chair of psychiatry ('chaire de clinique de pathologie mentale et des maladies de l'encéphale') in 1877 (launched in 1875), for which he had been presented by Charcot. Courtesy O. Walusinski, MD.

\section{Vascular Disease in General}

Four years after the previous presentation, Charcot reported a new case of arterial and capillary embolism into multiple organs from cardiac valvular disease, with comments on Virchow's theory [3, No. 27, p. 27]. He also emphasized the development of atheroma in arteries, and his major contribution here certainly was the princeps description of vascular intermittent claudication, which he reported in 1858 at the Sociéte de Biologie and published in the Gazette médicale de Paris in 1859 [3, No. 33, pp. 31-32]. In this work, Charcot referred to the previous presentation of this type of claudication in the horse by Bouley and Goubaux in 1831. This celebrated work still remains perfectly up-to-date, and very little has been subsequently added from a clinical point of view. Another major publication was the 1858 report of sudden death from pulmonary embolism associated with deep venous thrombosis [7], along with Benjamin Ball, at that time 
'interne' at La Pitié, and the future first holder of the chair of psychiatry ('chaire de clinique de pathologie mentale et des maladies de l'encéphale', launched in 1875), with the direct support of Charcot (fig. 2).

\section{Brain Infarction (Softening)}

In Charcot's last summary of his published work, the first subchapter on the nervous system concerns brain softening, hemorrhage and 'partial encephalitis' [3]. However, none of the 13 papers is specifically devoted to cerebral infarction. Charcot emphasized that brain softening is due to a 'regressive transformation of nervous substance', which is distinct from inflammation [3, No. 71, pp. 67-68]. This concept was in line with current studies, which were suggesting that brain softening was not the same condition as encephalitis, but it was at odds with the old tradition of the nineteenth century represented by the followers of Broussais [6]. Charcot also underlined the development of granular fatty infiltration after $24 \mathrm{~h}$ of stroke onset, while tissue abnormalities were hardly visible before. Along with his colleague and friend Alfred Vulpian, Charcot highlighted 'dizziness' ('étourdissement') as a precursor manifestation before infarction but rare with hemorrhage [3, No. 71, p. 67]. Charcot's work on ischemic stroke in fact appeared mainly through 3 studies, which he stimulated and directed in 1866, the 'stroke year' in Charcot's course. J.-S. Prévost and J. Cotard presented their work on 'Physiological and pathological studies on cerebral softening' [3, No. V.31, p. 178] to the Société de Biologie, and Ivan Poumeau published his doctorate thesis 'On the role of inflammation in cerebral softening' [3, No. V.27, p. 177], while Adrien Proust presented his thesis for the 'agrégation' professorship contest on 'Different forms of cerebral softening' [8] (fig. 3). In this work, the father of the famous novelist Marcel Proust showed the extent of the confusion which still existed on the pathological and physiopathological description of ischemic stroke, at a time when this field had been addressed mainly by German-speaking pathologists (Virchow, Cohnheim, Rokitansky) and isolated physicians in France (Rochoux, Rostan, Andral, Durand-Fardel) and Scotland (Abercrombie), who were not affiliated with emerging neurology [6].

In 1865, Charcot also contributed to a very interesting issue on stroke etiology in certain patients with cancer, reporting thrombotic occlusion of the middle cerebral artery leading to infarction in 4 women with uterine carcinoma [3, No. 32, p. 30]. While systemic venous throm-

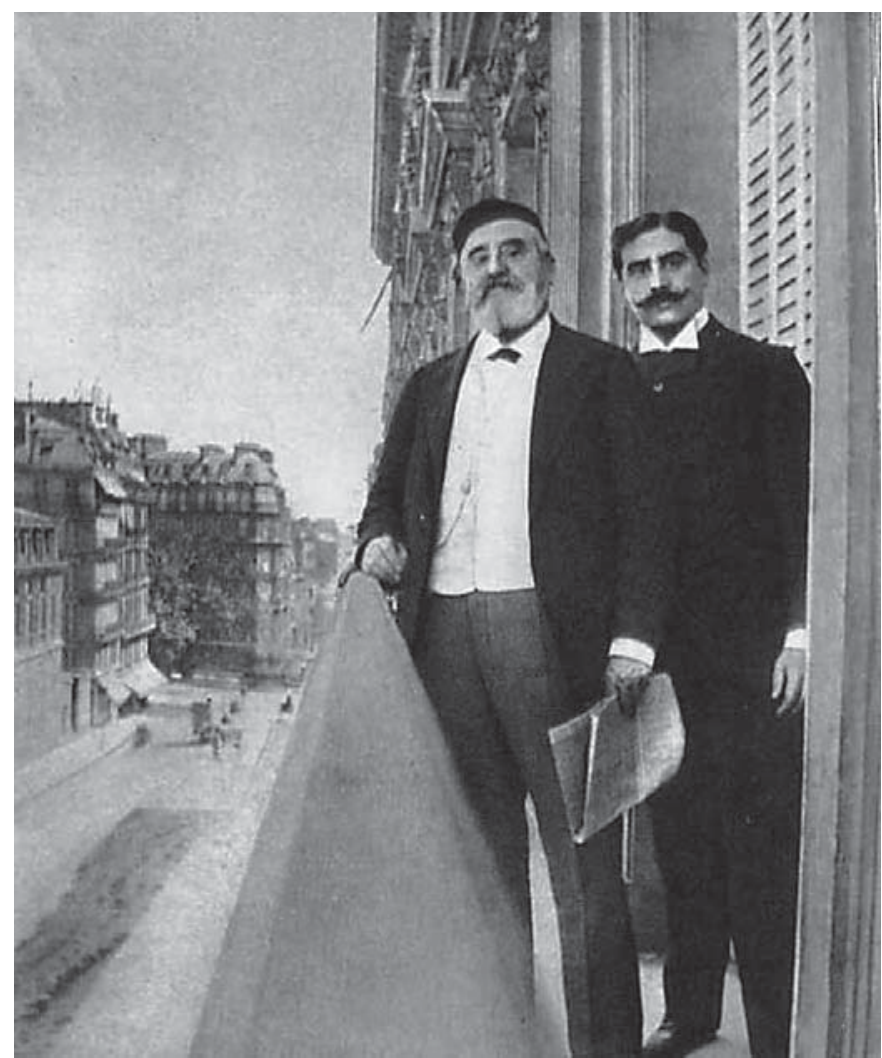

Fig. 3. Adrien Proust (1834-1903) with his son Robert Proust (future professor of urology and younger brother of Marcel Proust). Adrien Proust's 'agrégation' thesis (1866) on the different forms of brain softening was prepared under Charcot's supervision.

bosis associated with cancer had already been reported by Armand Trousseau (still known today as Trousseau's syndrome), Charcot highlighted the development of an arterial thrombus without underlying wall alteration. Eight years later, he directed A. Huret's doctorate thesis on embolism in the vertebral arteries [3, No. V.55, p. 183], but these works remained his only contributions on specific etiologies of ischemic stroke.

\section{Brain Hemorrhage}

Probably the most celebrated contribution by Charcot on stroke is his description of aneurysms on small cerebral arteries with his 'interne' Charles Bouchard. The paper entitled 'Note on an alteration of small arteries of the encephalon which can be considered as the most common cause of cerebral hemorrhage' was read at the So- 
ciété de Biologie in March 1866, before its publication as Bouchard's thesis and as an original article in the $\mathrm{Ar}$ chives de Physiologie in 1867 [3, No. 73, p. 69]. Charcot and Bouchard called these aneurysms 'miliary' because of their small size, nevertheless they are in arteries which can readily be seen without magnification. In fact, these aneurysms typically had a diameter $>1 \mathrm{~mm}$ and should not be confounded with dissecting aneurysms and moniliform dilatations. The authors insisted on the fact that miliary aneurysms were present on 'all cases' of cerebral hemorrhage which they had studied. Their development dated back to several years before the hemorrhage, with a progressive alteration in the vessel wall corresponding to a 'considerable nuclear proliferation of the adventice, as well as the lymphatic layer, while the muscular layer became atrophic'. For Charcot and Bouchard, this 'sclerous alteration' was different from atheroma, which explained for them why the coexistence of hemorrhage and softening was not common. One knows the story that Bouchard subsequently made a brilliant career in Paris, where he established a significant distance from his mentor. This reached its climax when Bouchard, as president of the jury for the 'agrégation' contest in 1892, intrigued to have his pupils succeed, while all 4 of Charcot's candidates were systematically rejected. Among them were Georges Gilles de la Tourette, who succeeded at a second attempt a couple of years later, and Joseph Babinski, who decided never to apply again, thus renouncing a faculty professorship for the rest of his career [9].

One year after the report by Charcot and Bouchard, R. Lépine presented at the Société de Biologie a work which had been directed by Charcot on 2 cases of subarachmoid hemorrhage [3, No. V.34, p. 179), while in 1869 , C. Durand's doctorate thesis expanded the discussion on the relationship between aneurysms and cerebral hemorrhage [3, No. V.42, p. 180]. No further original study on brain hemorrhage was made by Charcot after that date.

\section{Stroke Consequences}

Charcot and his pupils contributed several interesting works on specific long-term consequences after stroke, mainly during the 1860s and the first part of the 1870s, in parallel to the flourishing localization studies.

\section{Arthropathies}

In 1868, Charcot published a work on 'Arthritis in hemiplegia of cerebral origin' [3, No. 77, p. 73], emphasizing involvement of the limbs on the paralyzed side, main-

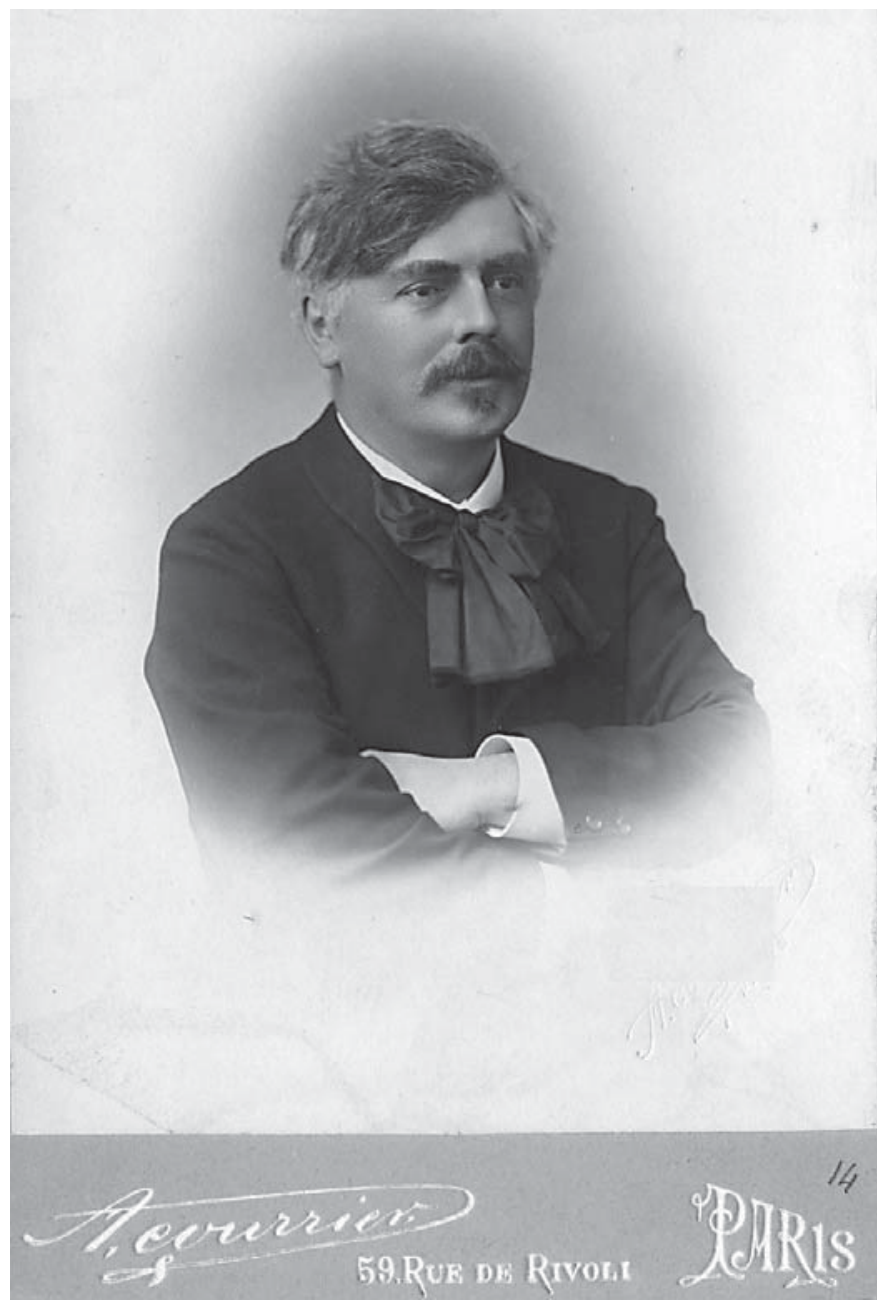

Fig. 4. Édouard Brissaud (1852-1909) became the interim successor of Charcot at his death, before Fulgence Raymond was appointed to the chair. His doctorate thesis (1880) dealt with contractures of hemiplegics and was prepared under Charcot's supervision. Courtesy O. Walusinski, MD.

ly in the upper limb. He reported a higher prevalence after brain softening than hemorrhage, with a typically delayed onset 2-4 weeks after stroke, often in association with 'contractures'. While the development of joint disorders after stroke had already been mentioned by Alison and Brown-Séquard, Charcot made the first detailed description and underlined the occurrence of a 'true synovitis', which he differentiated from more delayed, mechanical changes reported by Hitzig.

Sores

In the same year, Charcot reported a case of buttock sore on the side of hemiplegia [3, No. 76, p. 72]. He high- 
lighted the fact that the supine posture was not sufficient to lead to such sores and that local 'nutritional' tissue changes were necessary. The concept was expanded in the doctorate thesis (1868) of Bricquebec [3, No. V.40, p. 180], and in Charcot's Leçons sur les maladies du système nerveux a few years later [10], with emphasis on associated changes, such as modification of local temperature on the hemiplegic side.

\section{Contractures and Atrophy}

In his Leçons sur les localisations dans les maladies $d u$ cerveau, edited by his former 'interne' Désiré Bourneville in 1876 [10], Charcot commented on the 'state of muscular tone in permanent contractures of hemiplegics' (p. 238). With Bouchard and Cornil, he had also paid attention to the lack of increased tone in previously paralyzed limbs of patients who had just died [3, No. 80, p. 75]. Charcot also mentioned the development of amyotrophy in the hemiplegic limbs, which could be associated with secondary degeneration of the anterior horn of the spinal cord [3, No. 97, pp. 95-96], a topic which was expanded by his pupil Édouard Brissaud [11], the future founder of La revue neurologique, with Pierre Marie in the year of Charcot's death. Brissaud also devoted his doctorate thesis to that topic in 1880 [12] (fig. 4). In this work, Brissaud made an interesting report on 3 cases with secondary degeneration of the pyramidal tract after infarction in the territory of the middle cerebral artery, which he associated with the development of contractures. A few years before, Charcot himself had observed secondary degeneration of the cerebral peduncle after softening in the cerebral hemisphere [3, No. 94, pp. 92-93].

\section{Posthemiplegia Hemichorea}

Delayed abnormal movements in the process of recovery after hemiplegia were mentioned by Charcot, who stated that this disorder was often associated with hemianesthesia [3, No. 82, p. 76]. This finding was the trigger of Fulgence Raymond's 1876 doctorate thesis on hemichorea, hemianesthesia and tremor [13]. However, at the time, the focus was not specifically put on the thalamus, and this was done only in 1906 by Jules Déjerine and Gustave Roussy [14], who were from the school of Vulpian and never worked with Charcot. Seventeen years after his thesis, and after a short interim by Brissaud, Raymond would become his mentor's unexpected successor at the 'chaire de clinique des maladies du système nerveux', despite his often ridiculed past training as a veterinarian.

\section{Brain Localizations}

Brain localization research was a major topic of study by Charcot and his school, and although this work was not limited to vascular lesions, patients with stroke added largely to the study material. Charcot's main contribution to brain localization appeared in his 1876 book [10], which was translated into English, Russian and German within 2 years. Motor and sensory syndromes were analyzed with reference to cerebral lesions, inspiring 2 doctorate theses, by R. Veyssière in 1874 on hemianesthesia [15] and by $\mathrm{H}$. Clozel de Boyer in 1879 on cortical localizations [16]. Another important work was the 1877 doctorate thesis on centrum ovale lesions by Albert Pitres [17], with whom Charcot also critically addressed the issue of motor localizations within the cerebral cortex [3, No. 89, pp. 82-85]. Charcot also described pseudobulbar palsy with glossolabial involvement from bilateral deep hemisphere infarction [3, No. 124, p. 121; No. V.114, p. 195], with the help of Charles Féré, who later became his private secretary, before Georges Gilles de la Tourette. While Charcot's work on aphasia remains little known [18], he supported Paul Broca's studies and made an important contribution on the possibility of third frontal gyrus sparing in motor aphasia, along with Bouchard and Gilbert Ballet [3, No. V.24-25, p. 177; V.74, p. 186].

In conclusion, while summaries of main neurological studies by Charcot usually do not include stroke and cerebrovascular disease $[1,2]$, this survey shows that the contribution of the Salpêtrière master and his pupils was far from minor, at a time when this field was not well identified within emerging neurology [6]. The high number of important doctorate theses on this topic under Charcot's guidance also highlights his obvious skills in stimulating this kind of work among young physicians, who later often became great names in neurology.

References

1 Guillain G: J.-M. Charcot, 1825-1893, sa vie, son oeuvre. Paris, Masson, 1955

2 Gauchet M, Swain G: Le vrai Charcot. Paris, Calmann-Lévy, 1997.

3 Charcot JM: Exposé des titres scientifiques. Paris, Victor Goupy \& Jourdan, 1883.

4 Charcot JM: Études pour servir à l'histoire de l'affection décrite sous les noms de goutte asthénique primitive, nodosité des jointures, rhumatisme articulaire chronique (forme primitive), etc. Paris, Rignoux, imprimeur de la Faculté de Médecine, 1853.

5 Cotard J: Étude de l'atrophie partielle du cerveau. Paris, Lefrançois, libraire-éditeur, 1868. 
6 Paciaroni M, Bogousslavsky J: How did stroke become of interest to neurologists? A slow 19th-century saga. Neurology 2009;73: 724-728.

7 Charcot JM, Ball B: Sur la mort subite et la mort rapide à la suite de l'obturation de l'artère pulmonaire par des caillots sanguins, dans les cas de phlegmatia alba dolens et de phlébite oblitérante en général. Paris, Librairie Victor Masson, 1858.

8 Proust A: Des différentes formes de ramollissement du cerveau. Paris, Asselin, successeur de Béchet Jeune et Labé, Librairie de la Faculté de Médecine, 1866.

9 Philippon J, Poirier J: Joseph Babinski, a biography. Oxford, Oxford University Press, 2009.
10 Charcot JM: Leçons sur les localisations dans les maladies du cerveau faites à la Faculté de Médecine de Paris (1875), recueillies et publiées par Bourneville. Paris, Aux bureaux du Progrès Médical, Delahaye, libraires-éditeurs, 1876.

11 Brissaud E: De l'atrophie musculaire dans l'hémiplégie. Rev Mens Méd Chir 1879; I:616.

12 Brissaud E: Recherches anatomo-pathologiques et physiologiques sur la contractrure permanente des hémiplégiques. Aux bureaux du Progrès Médical, Delahaye \& Cie, libraires-éditeurs, 1880.

13 Raymond F: Étude anatomique, physiologique et clinique sur l'hémichorée, l'hémianesthésie et les tremblements symptomatiques. Paris, Librairie de la Faculté de Médecine, 1876.

14 Déjerine J, Roussy G: Le syndrome thalamique. Rev Neurol (Paris) 1906;14:521.
15 Veyssières R: Recherches cliniques et expérimentales sur l'hémianesthésie de cause cérébrale. Paris, Imprimerie de la Faculté de Médecine, 1874.

16 Clozel de Boyer H: Études topographiques sur les lésions corticales des hémisphères cérébraux. Paris, Aux bureaux du Progrès Médical, Delahaye \& Cie., libraires-éditeurs, 1879.

17 Pitres A: Recherches sur les lésions du centre ovale des hémisphères cérébraux étudiés du point de vue des localisations cérébrales. Aux bureaux du Progrès Médical, Delahaye, libraires-éditeurs, 1877.

18 Gasser J: Aux origines du cerveau moderne, localisations, langage et mémoire dans l'oeuvre de Charcot. Paris, Fayard, 1995. 